\title{
A Mystery of Academic and Industrial Skill Discordance among Business Graduates in Pakistan
}

\author{
Dr. Naveed Hussain Shah \\ Assistant Professor, Department of Management Sciences \\ University of Swabi, Swabi, KPK. \\ dr.naveedshah@uoswabi.edu.pk \\ Dr. Imtiaz Ali Khan \\ Vice Chancellor, University of Swabi, Swabi, KPK. \\ vc@uoswabi.edu.pk \\ Dr. Burhan Ali Shah \\ Assistant Professor, Quaid-i-Azam School Management Sciences \\ Quaid-i-Azam University, Islamabad \\ Dr. Faisal Khan \\ Assistant Professor, Department Of Management Sciences \\ University of Swabi, Swabi, KPK. \\ faisalkhan@uoswabi.edu.pk
}

\begin{abstract}
The study had explored the cognitive, non-cognitive and vocational skill required by the Pakistani organizations and found that there are various dimension that employer are interested among their potential employee. It was observed that Non cognitive are the more deficient one among the focused and as per gender is concerned their little response as per all skills however on Non-cognitive skills a bet more maturity exist among female candidates whereas the confidence level and lower literacy rate disturb their response on job market. Curriculum covering the Field specific theoretical and practical knowledge there is rare convergence on field specific practical knowledge. The study reveals a higher attention on industry academia collaboration through developing a high level of university-Industry linkages.
\end{abstract}

\section{Introduction}

Different patterns of skill mismatch can be expected in transition countries and emerging market countries. In many countries shortages of skills and skill mismatch have become the priority concern for makers of policy, particularly since the arrival of global economic crisis and its intensification through the crisis in the Eurozone. Romer (1994) presents endogenous growth model and highlighted that for growth, human capitalism one of the major resource. Therefore, in the primary concern for the education policy makers of education system the efficiency with which human capitals are developed and used on the 
labor market are the priority concerns for policy makers. Central to this concern is the process of matching skilled work force to the demands of job providers. There are two dimensions of this issue: The institutions of the labor market, education and training system. The effect of skill mismatch on labor market efficiency is adverse increasing joblessness above the levels that could possibly be achieved given the level of cumulative demand. Structural and frictional joblessness can be minimized by efficient matching and ensure that vacant posts are matched to employees with relevant skills and qualification (Petrolongo and Pissarides, 2001). On the other hand, the level of acquired skills levels is typically different from the desired level (Domadenik et al., 2013). According to Nordin et al. (2008), over and underutilization of skills and qualification influence performance. Likewise, Aracil and Velden (2008) affirmed that skill disparity negatively contributes toward organizational behaviors and is predictor of job dissatisfaction. Additionally, Kucel and Molina (2012) stated that over-utilization negatively affects workers' behaviors and cognitive abilities which may be manifested as low job satisfaction. DeGrip et al, (2007) further revealed that mismatch between qualification and job position affects cognitive abilities. Additionally' Aracil and Velden, (2008) posited that surplus and deficit in skills have negative association with satisfaction. Their study further emphasized exact matching between the acquired and required level of skills that perhaps stimulate workers toward the attainment of organizational objectives and effective performance. To manage skills mismatch, researchers, for example, Ramzan, (2004) and Ullah et al, (2010) recommended training based on needs analysis that confirm optimal performance, job satisfaction and occupational commitment.

Developed countries realized the issue of skill mismatch between industry and academia but developing countries are still behind. Recently Higher Education Commission (HEC) had taken the initiative to build provide different grant to overcome the issue. Many Pakistani youngsters are jobless due to mismatch of the knowledge acquired in the academia and required in the industry. Qualitative and quantitative data had been collected in three phases. During phase 1 and 2 skills were tapped required by employer. Third phase the study was progressed with thematic analysis while developing measuring instrument. Data was collected, tested through mean differences and Box plot among required and acquired skills and found that on average there is a higher lake of focus on non-cognitive skills as opposed to cognitive and vocational skills. The study suggests to ensure all the recent initiative taken by the HEC regarding Non-cognitive skills in its real essence and further recommends that there is an overall lake of all the skills as per employer responses.

By observing the fact and figures from the Pakistan Bureau of Statistics, we found that the female participation in labour force increased dramatically. This significant increase in female labour force changes the overall labour composition in Pakistan. Recently a report was published by Higher Education Commission Pakistan namely Employer's Perception Survey (2016). The result shows that the organization in Pakistan prefer male as comparison to female in recruitment and selection process. 
According to the Global Competitive Report 2016-2017, Pakistan labor market efficiency stands on 129 in 138 countries. Moreover, it is evident from the report that there is a mismatch between acquired and required level of skills. The study results of Uzair-ulHassan and Noreen, (2013) verify the same. Their study concluded that communication, strategic thinking, abstraction and research skills are the required skills by Pakistani organizations. However, there are very few studies available on this phenomenon with thematic analysis. The current study will try to fill this gap. The main aim of this research is to find out the cognitive, non-cognitive and vocational skills required by the organization, and share this information with universities to help them design the curriculum accordingly.

The study had explored the cognitive, non-cognitive and vocational skill required by the Pakistani organizations and found that there are various dimension that employer are interested among their potential employee. These skills set after going through thematic analysis are Cognitive Skills such as Ability to learn (Memory), Problem-solving ability, Time management, Ability to work under pressure, Decision making, Creativity, NonCognitive Skills such as Willingness to work, Ability to work as part of a team, Negotiating, reaching agreements, Organization and leadership skills, and Vocational Skills are Field-specific theoretical knowledge, Field-specific practical knowledge, Oral communication skills, Written communication skills, Computer skills, English language skills. As far Gender is concerned their little response as per skills however on Noncognitive skills a bet mature among female candidates whereas the confidence level disturb their response. Curriculum covering the Field specific theoretical and practical knowledge it was observed that there are higher concerned regarding Field specific practical knowledge requiring a higher concerned industry academia distances and a need strengthening university-Industry linkages.

There is further need for including these skills set as the target of their strategic planning in improving their outgoing students and research output the universities. There are some suggested instruments that better asses our performance. As per Industry academia linkages is concerned it should be the prior area of budget allocation concern. The workshop concerned will be organized as the corona pandemic is over.

The study contribute to the Economy and Society as it is highlighting the direly searched skills by the employer as well as the scarce skills highly needed to be focused in enhancing Employability of Student at different level of education and mending the shattered trust and confidence on education system or our institutions. This study ensure that there is a need of the skills if acquired as defined and explored by the study then there is no difference public and private sector employees. This also dig out during interview from the officials that there is lake of job creation in Government therefor students should be encouraged to opt for private sector jobs and enhance their skills while working rather than being unemployed

In fact, the basic motive behind this study is to see how the skills mismatch between the graduates and employment organizations can be minimized. This will be operationalized through a research study on what skills are required by the employment organizations in Pakistan and do graduates 
learn these skills in universities. Hence, the findings of the study will be shared with faculty members of universities in Khyber Pakhtunkhwa by organizing workshop on "Skills mismatch" the ultimate aim of this future workshop will be to train the faculty with skill mismatch, which will be followed by designing curriculum for each university. The final report on the progress of these mismatch skills if possible will be submitted to HEC Islamabad. The above practice of training and development of skill mismatch for universities can be expanded to other universities of Pakistan. A number of universities are running their program with inappropriate mission and vision and further there are courses deficiencies not covering the market demands or a number of skills are not targeted in academia. After thorough work out of the project curriculum for the highly needed skills can be designed and commercialize. There can be a separate section recommended on the basis of the study to align for industry academia partnership to foster future orientation of the student in job market.

\section{Methodology}

\subsection{Data Collection}

Aiming at the qualitative and quantitative nature of the research objectives (Explorative and Validation), the research design of the study is proposed as follow:

The study will be carried out in three phases:

\subsection{First Phase}

The study was conducted while considering major organizations with referrals in Pakistan that there is an ease of the data collection from their top and middle management of their experiences regarding acquired and required skills between industry and academia. They were familiarized with skill set given in the study of Bunk (1994) and Kohler (2004) as set in the objective of the study while distributing pamphlets to them covering the following

\subsection{Cognitive Skills (Hard skills)}

These skills includes Memory, Motor skills, visual and spatial processing and executive functioning

\subsection{Non Cognitive Skills}

These skills are composed of motivation, effort, interpersonal and self-efficacy.

\subsection{Vocational Skills}

These include theoretical understanding and practical application of the knowledge acquired, lingual and technological skills

The organizational profiles majorly providing job opportunities to graduates are as under.

Habib Bank Limited

National Bank Limited

National Accountability

Bureaue

Pakistan

Telecommunication

authority

Pakistan International

Airline
Pakistan Development

Economics

Oil and Gas

Development

Corporation

National Bank of

Pakistan

Khushali Bank Limited

Bank Alhabib Limited

JS Bank
Right to Information

Pakistan

Telecommunication

Authority

National Development

Complex

Sui Northern Gas

pipeline Limited 


\section{Second Phase}

Interviews were started and after having access to interviewing Human resource managers the researcher distributed the pamphlet developed for recalling the skillset mentioned in phase 1.Different questions were asked as per objective of the study and the following process of thematic analysis was followed as given in the table1 given below . After thoroughly reading and rereading the interview responses written at the time of interview it was found that now saturation of the respective responses is occurring after interviewing fifteen top Human Resource Management officials. Those responses were transcribed and then following the process as established in the process of table 1.

The Interviews were posing questions as per Employer regarding establish their experiences regarding acquired and required skill and opinion about the prevailing perception of the stakeholders regarding industry and academia differences demand in the job market. Further questions were asked about varying aspects of the skills need more attention. Identify the responsible for the industry academia differences. Employer were also investigated for their responses the basis of gender too.

\subsection{Sampling}

The unit of analysis is the major employer organizations of Pakistan. The data will be collected from the middle and top management involved in employee selection committee. In qualitative phase of study (phase 1 and 2), sample size was based on the themes saturation reaching fifteen officials from the organization profile listed by names. In the quantitative phase of the study (phase 3), the total sample size for quantitative survey was 250 .

\section{Statistical Analysis}

\subsection{Data Analysis}

The data collected in phase 1 and phase 2 will be analyzed using thematic analysis approach for knowing the themes of "required skills". The survey based quantitative data was analyzed using mean differences table representing skill differences among required acquired given in Table 3 and Table 4.

The key interviews were transcribed below

"HBL officer was interviewed who made the family support and dwelling as one of the hindrances in the success of the majority of the individual personality development focusing on soft skills development. These includes"

"There had always been a space in industry and academia and we can only talk about the differences and none of the related is serious to dissolve it. Here too soft skills were mentioned as the key indicator in success of the individual"

"There had always been a phenomenon of copy paste with looking into the context of the organization and for this both of the parties are responsible. There is a claim of providing each and every facility to nurture the nation but non seriousness is prevailing on both the side".

"There are missing as personality development at academia and home both it is considered that capacity building is a joint responsibility of the all stake holder that students can developed the whole of their as per their memory, knowledge and situation handling".

"Individual are judged on the basis of their entire attribute as per their adherence to the interview setting being active with knowledge depth and expressive powers before the board and also responding as per the question asked".

"As per experience there is continues lack of expressive skills and confidence among majority of the individual interviewed. It is admitted that here is a joint mishandling on behalf of the entire 
stakeholder fulfilling our responsibility to our future generation". The rest of the interviews are transcribed in the table 1 as for thematic analysis to identify the required skills.

Theme Saturation is highlighted in the word cloud of the interviews conducted given in Figure 1.

\subsection{Third Phase}

The conceptual model is developed and validated through a factor analysis and reached a set that questionnaire regarding required and acquired will be distributed as obtained from the thematic analysis carried out in Phase 1 and 2 of the study and the finding will be generalized to organizations working in Pakistan.

\section{Tables, Graphs and Figures}

\section{Table 1: Frame of the Initial Coding}

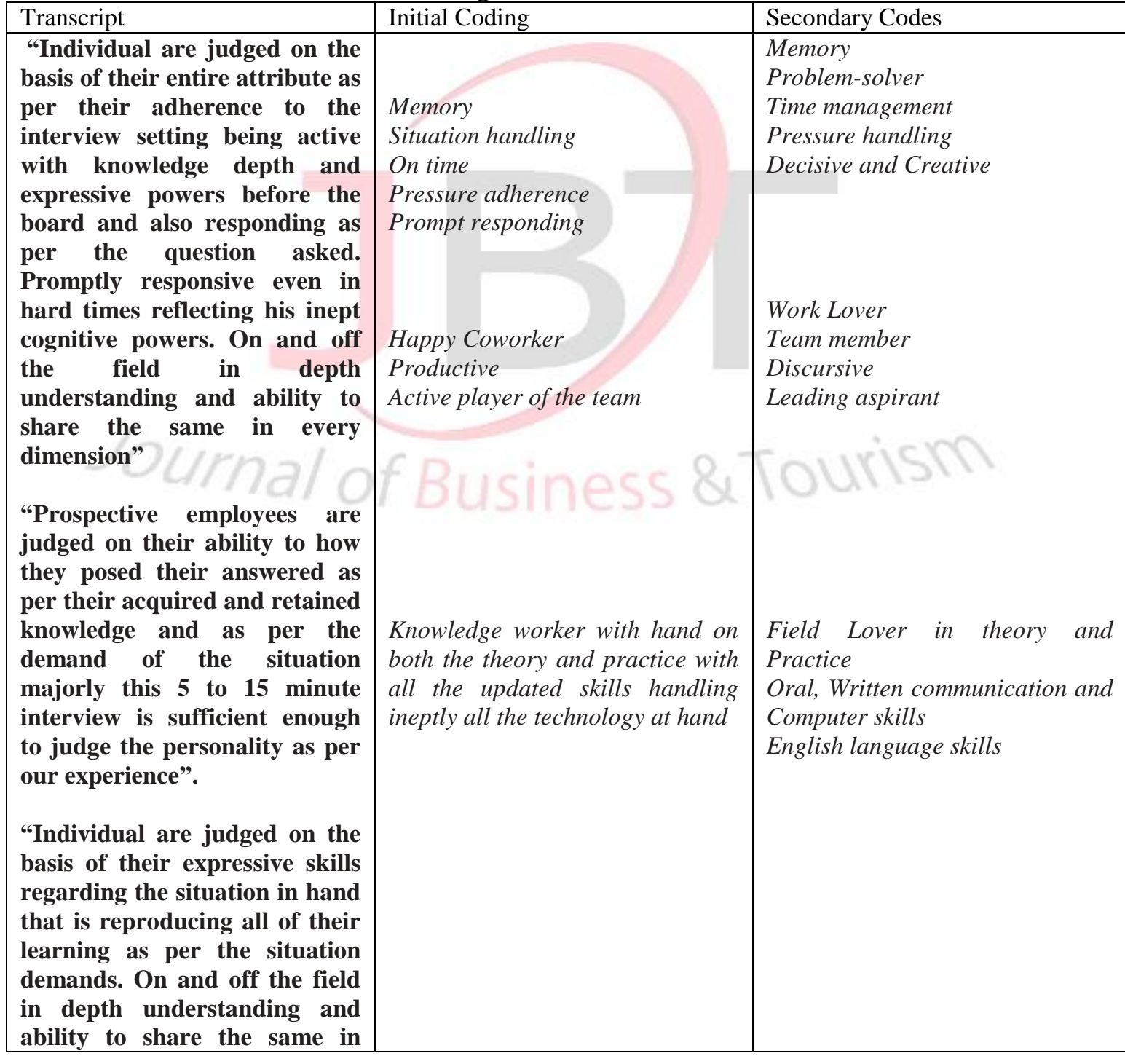


every dimension"

"It is considered as per the pamphlet shared that we value all the skills but where there is missing link it on part of the non-cognitive skills such as being happy working in teams sharing the responsible part".

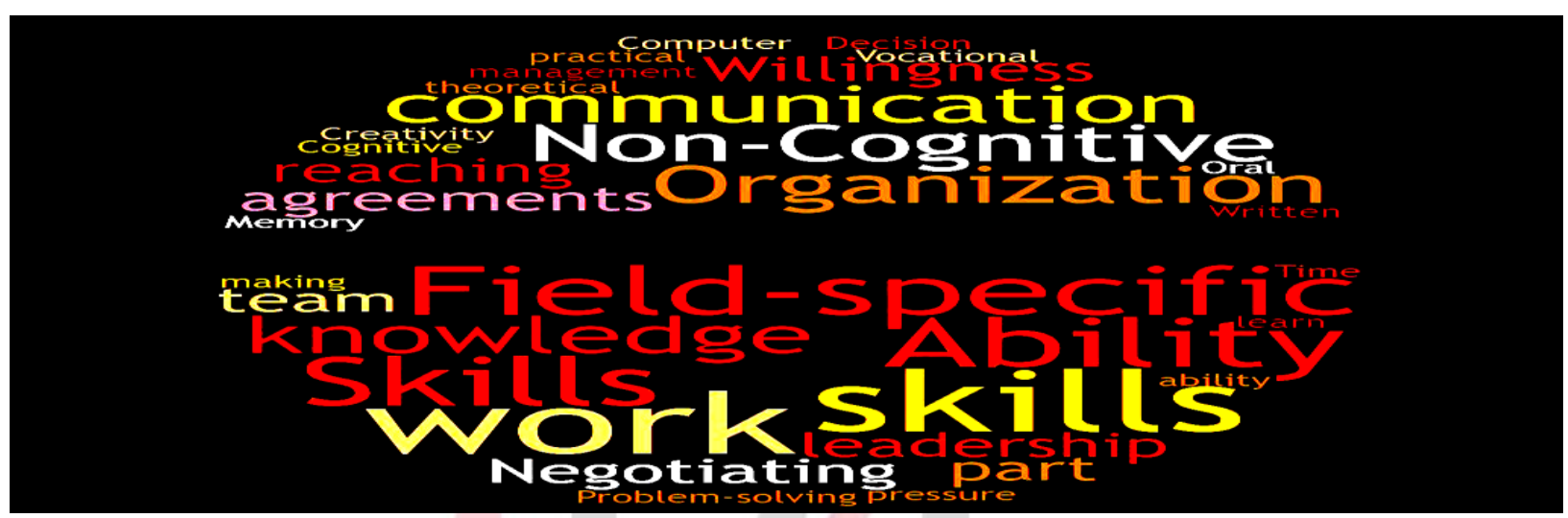

Figure 1

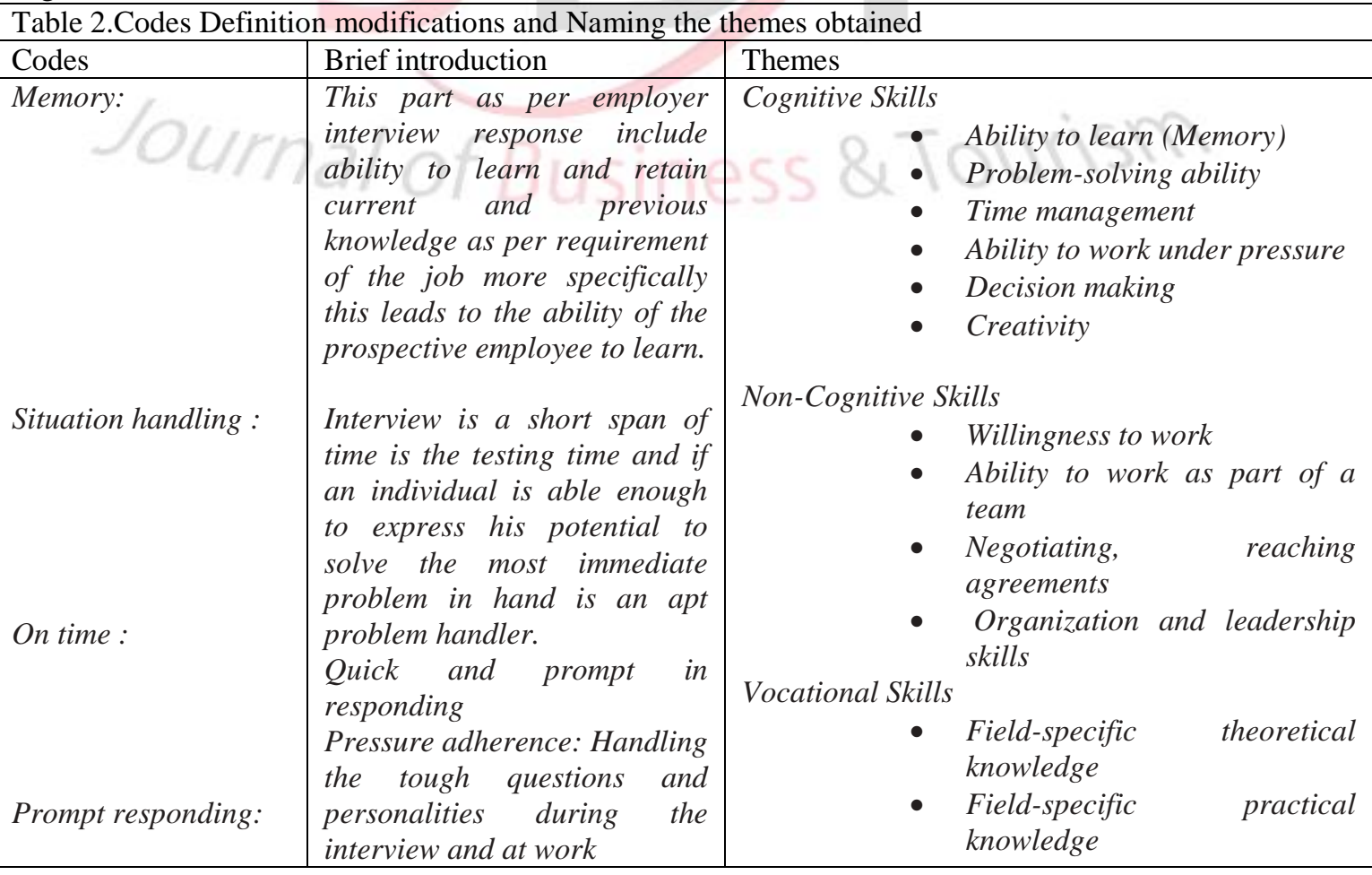




\begin{tabular}{|c|c|c|}
\hline $\begin{array}{l}\text { Happy Coworker: } \\
\text { Productive: } \\
\text { Knowledge worker: }\end{array}$ & $\begin{array}{l}\text { Decisive and creative } \\
\text { response. } \\
\text { Willing and motivated fresh in } \\
\text { all the burdens of the work. } \\
\text { Active player of the team } \\
\text { with hand on both the theory } \\
\text { and practice with all the } \\
\text { updated skills handling ineptly } \\
\text { all the technology at hand }\end{array}$ & $\begin{array}{ll}\text { - } & \text { Oral communication skills } \\
\text { - } & \text { Written communication skills } \\
\text { - } & \text { Computer skills } \\
\text { - } & \text { English language skills }\end{array}$ \\
\hline
\end{tabular}

\section{Box Plot 1.}

For the

responses

Varying

Competencies
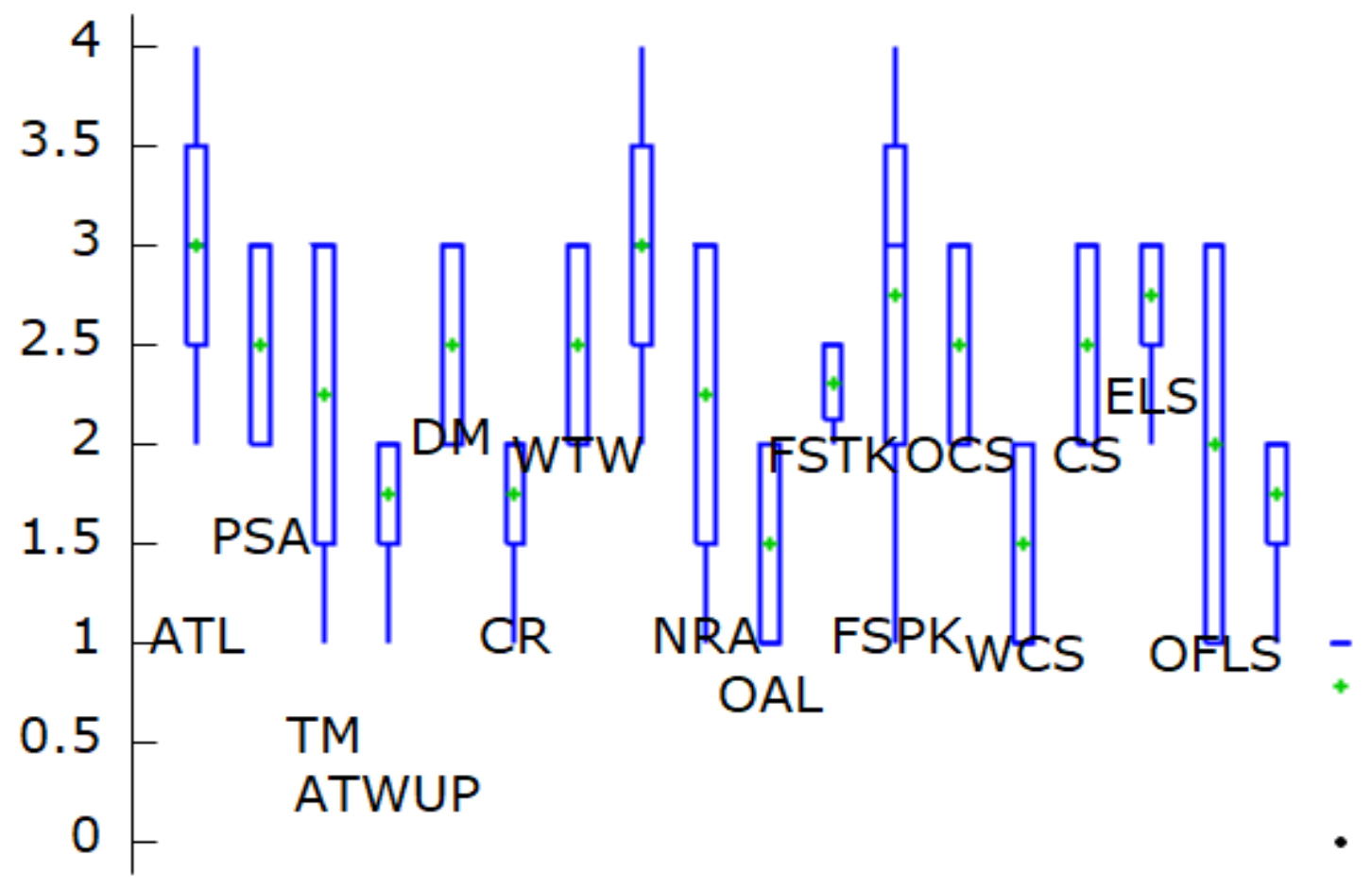

Box plot 1 
Box plot 1. Abreviations are Ability to Learn (ATL),Problem Solving Ability(PSA), Time Management(TM),Ability to work under pressure(ATWUP),Decsion Making(DM),Creativity(CR), Willingness to Work(WTW),Negotiating and Reaching Agreement(NRA),Organization and Leadership(OAL),Field Specific Theoretical Knowledge(FSTK), Field Specific Practical Knowledge(FSPK), Oral Communication Skills(OCS), Written Communication Skills(WCS), Computer Skills(CS), English Language Skills(ELS), Other Foreign Language Skills(OFLS)
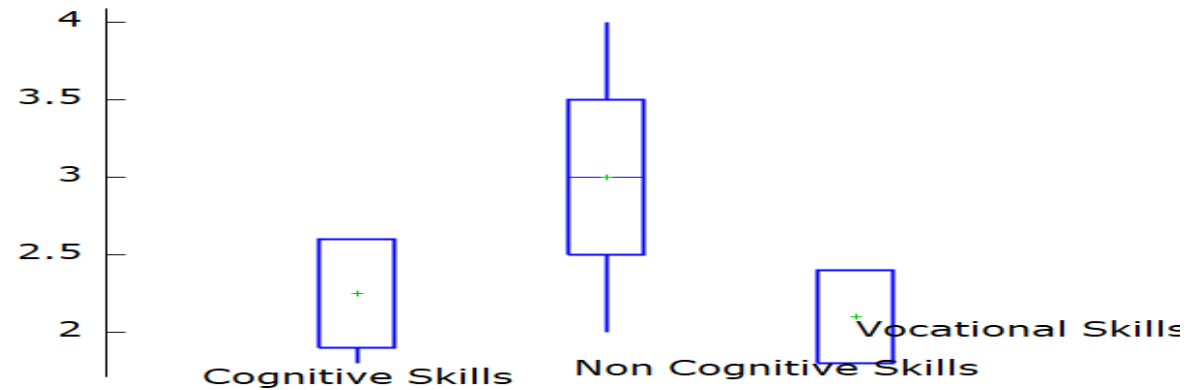

Box plot 2

\section{Table 3}

\begin{tabular}{|c|c|c|c|}
\hline Skills(Scaled from 1-4) & Required Level (1) & Acquired level(2) & Mismatch(3)=(2)-(1) \\
\hline 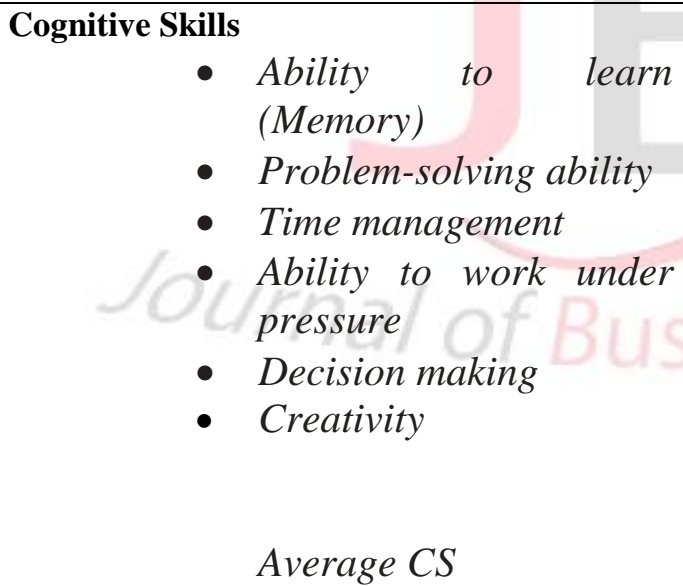 & $\begin{array}{l}3.00 \\
2.51 \\
2.25 \\
1.75 \\
2.50 \\
1.75 \\
2.2933\end{array}$ & $\begin{array}{l}2.94 \\
1.59 \\
1.4 \\
1.02 \\
1.47 \\
1.28 \\
1.616667\end{array}$ & $\begin{array}{l}-0.06 \\
-0.92 \\
-0.85 \\
-0.73 \\
-1.03 \\
-0.47 \\
-0.67667\end{array}$ \\
\hline $\begin{array}{l}\text { Non-Cognitive Skills } \\
\bullet \quad \text { Willingness to work } \\
\bullet \quad \text { Ability to work as part } \\
\text { of a team } \\
\bullet \quad \text { Negotiating, reaching } \\
\text { agreements and } \\
\text { Organization } \\
\text { leadership skills } \\
\text { Average NCS }\end{array}$ & $\begin{array}{l}1.50 \\
3.00 \\
\\
2.25 \\
1.50 \\
2.06\end{array}$ & $\begin{array}{c}0.90 \\
2.25 \\
\\
1.28 \\
0.69 \\
1.28\end{array}$ & $\begin{array}{l}-0.97 \\
-0.81 \\
-0.78\end{array}$ \\
\hline $\begin{array}{c}\text { Vocational Skills } \\
\bullet \quad \text { Field-specific }\end{array}$ & 2.75 & 2.34 & -0.41 \\
\hline
\end{tabular}




\begin{tabular}{|l|l|l|l|}
\hline $\begin{array}{l}\text { theoretical knowledge } \\
\text { Field-specific practical } \\
\text { knowledge }\end{array}$ & 2.50 & 1.25 & -1.25 \\
Oral communication & 1.50 & 0.84 & -0.66 \\
$\begin{array}{l}\text { skills } \\
\text { Written communication } \\
\text { skills }\end{array}$ & 2.50 & 1.87 & -0.63 \\
- Computer skills & 2.75 & 2.23 & -0.52 \\
English language skills & 2.00 & 1.5 & -0.5 \\
- Other foreign language & skills & 1.22 & -0.53 \\
\hline Average VS & 2.25 & 1.60 & -0.64 \\
\hline
\end{tabular}

Note. In column (1) the averages for groups of skills are all significantly different $(p<.01)$ except those for Average CS,NCS, and VS, in column (2) only the average for NCS is significantly different from that of other groups; in column (3) the averages for groups of skills are all significantly different $(p<.01)$ except those for CS, and VS.

Table 4.

\begin{tabular}{|c|c|c|c|}
\hline Skills(Scaled from 1-4) & Required Level (1) & Acquired level(2) & $\operatorname{Mismatch}(3)=(2)-(1)$ \\
\hline $\begin{array}{c}\text { Cognitive Skills } \\
\bullet \quad \text { Male } \\
\bullet \quad \text { Female } \\
\text { Non-Cognitive Skills } \\
\bullet \quad \text { Male } \\
\bullet \quad \text { Female } \\
\text { Vocational Skills } \\
\bullet \quad \text { Male } \\
\bullet \quad \text { Female }\end{array}$ & $\begin{array}{l}3.01 \\
2.36 \\
1.45 \\
1.85 \\
2.51\end{array}$ & $\begin{array}{l}1.64 \\
1.02 \\
1.29 \\
1.87\end{array}$ & $\begin{array}{l}-0.72 \\
-0.43 \\
-0.56 \\
-0.64\end{array}$ \\
\hline
\end{tabular}

Note. In column (1) the averages for groups of skills are all significantly different for male and female as $(p<.01)$ CS,NCS, and VS, in column (2) only the average for NCS is significantly different from that of other groups; in column (3) the averages for groups of skills are all significantly different $(p<.01)$ 


\section{Results and Discussion}

Results and Discussion section is composed of the detail interpretation along with discussion with respect to the literature about Boxplot 1 and 2 and Mean Difference Table No.4

\subsection{Interpretation of the Graphical representations in the form of Box plots}

The questionnaire data collected from the employers was processed through the Gretl and the following box plot and differences chart were obtained. The box plot one is about the detailed responses against each skill and it was found that highly valued skills were Ability to learn denoted by ATL, Willingness to work denoted WTW, Field Specific Knowledge denoted by FSPK. Ability to work under pressure denoted by ATWUP and Creativity are rarely considered whereas Decision Making (DM) Computer Skills (CS) and English Language skills (ELS) were moderately responded.

\section{Box plot 2.}

For Responses against Cognitive Skills, Non Cognitive and Vocational Skills

This plot can illustrated as exhibiting a higher response rate towards non- cognitive skills as compare to cognitive and vocational skills representing a need of focus on noncognitive skills. These skills are highlighted by the study and there is a dire need of addressing this area at industrial and academic level both.

\subsection{Interpretation of the Table 4}

The skill set tested for as used at CHEERS, STEP and TUNING and developed through our thematic analysis are resembling and were tested for the as given in Bunk (1994) and Kohler (2004) classifications required and acquired knowledge and competencies. The employers responses were investigated with respect $t$ what skills they require from graduates. Table 4, column 1 includes the average score assigned to each skills various groups of skills, using a $1-4$ point scale (where 1 is the lowest and 4 the highest). In this scenario are the skills are equally important as per our interviews and here too majority of the employers do focus these skill set. Skills such as willingness to work, the ability to learn, and the ability for teamwork are highly valued. Similarly it is proved that the ability to communicate, field-specific knowledge, computer skills, time management, and problem-solving abilities as well as the ability to work under pressure hold a high or very high level of importance for four out of five surveyed employers (Coll \& Zegwaard, 2006, and Hodges \& Burchell, 2003, obtained similar results).As opposed to the study of (Burchell, Hodges, \& Rainsbury, 2001; Hodges \& Burchell, 2003) non cognitive skills were more valued in Pakistan although on average there is an overall shortage of the entire skills given by the negative signs.

In Pakistan companies value Negotiating and reaching agreement and problem solving ability and field specific practical sharing similarities as per the result of Peter D.Hart Research Associates, Inc. (2008) and in Heldrich (2005).However, results are quiet far from the required level (3.00) expected by employers. As Table 4, column 3 shows, the 
differences in required and acquired level of competencies as seen in(Hodges\&Burchell,2003). Higher differences of skills in decision-making, ability to negotiate and reach agreements, the ability to resolve problems, and organization and leadership abilities. Few of the deficiencies as per time-management, working under pressure, and the ability for teamwork were also observed and is in continuum with research studies (Candy \& Crebert, 1991; Crebert et al., 2004). The opposite is incurring in the situation of willingness which is in peculiar (-0.6) whereas mismatches are greater in Non-cognitive skills as opposed to vocational and cognitive skills (these results are very similar to those obtained by Candy \& Crebert, 1991, but opposite to Allen \& Ramaekers, 2006).

The questionnaire was distributed among 55 female employers and 195 male responded and during the interview session at thematic analysis stage there is a demand for skill not for gender and though there is a natural tendency of male to be high at cognitive skills where as Non-Cognitive were more developed in female however there is an insignificant relation between the skill set and gender.

Table 5. of the study had taken mean differences for skill level among male and female and found that on average non- cognitive skills are showing less difference as compare to male however on cognitive an vocational skills level male candidate are over performing the other counterpart.

In this study we have observed that the competencies that employers value the most in graduates are technical field-specific knowledge, as well as interpersonal skills. It was found that employers are giving more importance to field specific knowledge as well as no-cognitive skills. Furthermore negotiating self-motivation to work and organizational leader ship were important as given in the Box plot for Non cognitive skills. Companies are assessing individuals on technical manner ability to learn stand out at top among the cognitive skills however some of the vocational and soft skills of skills Next, companies evaluate the competencies in a methodological manner, among which a capacity to learn stands out. Finally, companies also consider cognitive soft abilities, primarily communication and computer skills and, to a lesser extent, knowledge of languages but English literacy at time overplay its role. There are also some aspect that stresses on the availability of knowledge more practice base rather than theory however majority of the employer are trapped in supporting the theory based responses. Work environment seems different there is a need of devising pilot or real organization where student can develop the skills of real time learning practicing decision making, negotiating and reaching agreements, organization and leadership, problem solving, time management, teamwork, and working under pressure. As for oral and written communication, computer skills and languages there is a lesser differences in the current lot of the prospective employees. Recent graduates are highly motivated to work 
also given in the qualitative result. Students' grades are the least bothered area of the employer except in the eligibility step imposed by the organizational policy.

\section{Conclusion}

The study had explored the cognitive, non-cognitive and vocational skill required by the Pakistani organizations and found that there are various dimension that employer are interested among their potential employee. These skills set after going through thematic analysis are Cognitive Skills such as Ability to learn (Memory), Problem-solving ability, Time management, Ability to work under pressure, Decision making, Creativity, NonCognitive Skills such as Willingness to work, Ability to work as part of a team, Negotiating, reaching agreements, Organization and leadership skills, and Vocational Skills are Field-specific theoretical knowledge, Field-specific practical knowledge, Oral communication skills, Written communication skills, Computer skills, English language skills. As far Gender is concerned their little response as per skills however on Noncognitive skills a bet more maturity exist among female candidates whereas the confidence level and lower literacy rate disturb their response job market. Curriculum covering the Field specific theoretical and practical knowledge it was observed that there are higher concerned regarding Field specific practical knowledge requiring a higher concerned for industry academia distances and a need for strengthening universityIndustry linkages.

\section{References}

Allen, J. P., \& Ramaekers, G. W. M. (2006). Survey among employers of alumni from the Faculty of Economics and Business Administration of Universiteit Maastricht. ROA Reports, (1E).

Bunk, G. P. (1994). Teaching competence in initial and continuing vocational training in the Federal Republic of Germany. Vocational Training European Journal, 1(94), 8-14.

Candy, P. C., \& Crebert, R. G. (1991). Ivory tower to concrete jungle: The difficult transition from the academy to the workplace as learning environments. The Journal of Higher Education, 62(5), 570-592.

Coll, R. K., \& Zegwaard, K. E. (2006). Perceptions of desirable graduate competencies for science and technology new graduates. Research in Science \& Technological Education, 24(1), 29-58.

Crebert*, G., Bates, M., Bell, B., Patrick, C. J., \& Cragnolini, V. (2004). Developing generic skills at university, during work placement and in employment: graduates' perceptions. Higher Education Research \& Development, 23(2), 147-165.

Domadenik, P., Farcnik, D., \& Pastore, F. (2013). Horizontal mismatch in the labour market of graduates: The role of signalling. 
García-Aracil, A., \& Van der Velden, R. (2008). Competencies for young European higher education graduates: labor market mismatches and their payoffs. Higher Education, 55(2), 219-239.

Heldrich, J. J. (2005). Survey of New Jersey Employers to Assess the Ability of Higher Education Institutions to Prepare Students for Employment. New Jersey Commission on Higher Education.

Hodges, D., \& Burchell, N. (2003). Business graduate competencies: Employers' views on importance and performance. International Journal of Work-Integrated Learning, 4(2), 16.

Kohler, W. (2004). Eastern enlargement of the EU: a comprehensive welfare assessment. Journal of Policy Modeling, 26(7), 865-888.

Kucel, A., Molina, I. F., \& Raya, J. M. (2016). Over-education and its opportunity cost in Japan. Asia Pacific Education Review, 17(2), 299-312.

Peter D. Hart Research Associates, I. (2008). How should colleges assess and improve student learning?: Employers' views on the accountability challenge. A Survey of Employers Conducted on behalf of: The Association of American Colleges and Universities.

Ramzan, M. (2004). Levels of information technology (IT) applications in Muslim world libraries. The Electronic Library.

Ratnala, V. R., Kiihne, S. R., Buda, F., Leurs, R., de Groot, H. J., \& DeGrip, W. J. (2007). Solid-state NMR evidence for a protonation switch in the binding pocket of the H1 receptor upon binding of the agonist histamine. Journal of the American Chemical Society, 129(4), 867-872.

McMurray, S., Dutton, M., McQuaid, R., \& Richard, A. (2016). Employer demands from business graduates. Education+ Training.

Ullah, N. (2010). ANFIS Based Models for Accessing Quality of Wikipedia Articles.

Uzair-ul-Hassan, M., \& Noreen, Z. (2013). Educational Mismatch between Graduates' Possessed Skills and Market Demands in Pakistan. International Education Studies, 6(11), 122-129.

World Economic Forum. (2017). The global competitiveness report 2016-2017.

Zakaria, E., \& Nordin, N. M. (2008). The Effects of Mathematics Anxiety on Matriculation Students as Related to Motivation and Achievement. Eurasia Journal of Mathematics, Science \& Technology Education, 4(1). 